\title{
$\nabla$ \\ An Ayurvedic Protocol to Manage Retinitis Pigmentosa - A Case Report
}

\section{IJCRR}

Section: Healthcare

Sci. Journal Impact

Factor: 6.1 (2018)

ICV: 90.90 (2018)

Scopus'

\section{Narayanan Namboothiri Narayanan' ${ }^{1}$, Aravind Kumar², Krishnendu Sukumaran², Agaja Peethambaran Leena ${ }^{3}$}

'Chief Physician and President, Sreedhareeyam Ayurvedic Research and Development Institute Nelliakkattu Mana, Kizhakombu Koothattukulam, 686662, Ernakulam Dt., Kerala, India; ${ }^{2}$ Research Coordinator, Sreedhareeyam Ayurvedic Research and Development Institute Nelliakkattu Mana, Kizhakombu Koothattukulam, 686662, Ernakulam Dt., Kerala, India; 3]unior Medical Officer, Sreedhareeyam Ayurvedic Research and Development Institute Nelliakkattu Mana, Kizhakombu Koothattukulam, 686662, Ernakulam Dt., Kerala, India.

\section{ABSTRACT}

Introduction: Retinitis pigmentosa (RP) is a clinically and genetically heterogeneous group of inherited retinal disorders that almost invariably occur in both eyes and often result in blindness in the middle-age and advanced age groups. According to Ayurveda, the cardinal symptoms of night blindness and diminished vision seen in RP may be correlated with Kapha-Vidagdha Drishti, a Drishtigata Roga or disease of vision.

Case: A 38-year-old male presenting with blurring of vision since 2017 and diminished night vision since childhood is presented here.

Intervention: The patient underwent two courses of in-patient Ayurvedic management consisting of Panchakarma (bio-purification) therapy, oral medicines, and external therapies for the eyes and head.

Results: Assessment showed improvement in both unaided distant visual acuity (DVA) and visual field analysis.

Conclusion: The main aim of management was to preserve and give a better quality of vision for the patient. The results indicate the potential of Ayurvedic treatments to manage and maintain vision in retinitis pigmentosa.

Key Words: Case report, Retinitis pigmentosa, Kriyakalpa, Panchakarma therapy

\section{INTRODUCTION}

Retinitis pigmentosa is a genetically pre-determined retinal dystrophy characterized by progressive degeneration of rod photoreceptors, cone photoreceptors, and retinal pigment epithelium in that order. Inflammation, implied by the term is not a part of its pathophysiology. The prevalence of RP amounts to one case in every 4000 persons. ${ }^{1}$ A search on $\mathrm{RP}$ in PubMed amounted to 7000 references and was characterized by desirability for both experimental and clinical research. ${ }^{2}$ Occurrence may be either isolated or either autosomal dominant, autosomal recessive, or X-linked by inheritance. Apart from genetic predisposition, there are no other known risk factors. ${ }^{3}$ RP's primary symptom is night blindness, with advanced cases presenting with a ring-like scotoma in the visual field that gradually progresses to "tunnel" vision. As there is no definite cure for RP in allopathic medicine, alternative management options may be explored.

\section{METHODOLOGY}

The efficacy of an Ayurvedic treatment protocol to manage a case of RP was assessed in this report. It was prepared according to the Case Report (CARE) guidelines to ensure transparency and effectiveness in reporting ${ }^{4}$. Although institutional ethical clearance was not required for this study, written informed consent was obtained from the patient before detailing his case.

\section{CASE PRESENTATION}

A 38-year-old non-diabetic and non-hypertensive male presented to the OPD of Sreedhareeyam Ayurvedic Eye Hospital and Research Center, with blurring of vision since 2017 and difficulty in night vision since childhood. He was born to non-consanguineous parents and his mother had a full-term, normal delivery (FTND) with no postpartum complications.

\section{Corresponding Author:}

Dr. Aravind Kumar, M.S. (Ay), Sreedhareeyam Ayurvedic Research and Development Institute Nelliakkattu Mana, Kizhakombu Koothattukulam, Ernakulam Dt., Kerala, 686662; Phone:9400630608; Email: aravind0511@gmail.com

ISSN: 2231-2196 (Print)

Received: 02.05.2020
ISSN: 0975-5241 (Online)

Revised: 05.06.2020
Accepted: 18.06 .2020
Published: 05.07 .2020 
He started to gradually develop difficulty in night vision around the age of 3, for which he was prescribed vitamin A tablets. He developed pain in distant vision around the age of 7 , for which he was diagnosed with myopia and prescribed corrective spectacles. The glass power progressively increased over time, for which he was prescribed cylindrical lenses in 2014. In 2018, he was diagnosed with retinitis pigmentosa after a complete ophthalmic and genetic examination. He was advised to protect his eyes from ultraviolet radiation, avoid smoking, and take plenty of fruits, vegetables, and foods rich in omega-3 fatty acids. Genetic counseling was also recommended. He had his first consultation at Sreedhareeyam Eye Hospital in September 2018.

His sister also suffered from night blindness. His bowel, appetite, and micturition were normal and his sleep was sound. He occasionally consumes alcohol. Review of systems and vital signs were normal. He weighed $90 \mathrm{~kg}$ and was $172 \mathrm{~cm}$ tall. His Dasavidha Pariksha (ten parameters of examination $)^{5}$ findings are listed in Table 1.

Unaided distant visual acuity (DVA) was LogMAR 0.602 in both eyes (OU). Aided DVA was LogMAR 0.477 in the right eye (OD) and LogMAR 0.301 in the left eye (OS), which was improvable to LogMAR 0.301 OU with a cylindrical lens of 1 diopter OD and 1.25 diopter OS. Near vision was N6 OU. Anterior segment examination was normal OU. Direct and consensual pupillary reflexes were normal OU.

Posterior segment examination by direct ophthalmoscopy showed a slightly cloudy foveal reflex OU, pale optic disc OU, normal macula OU, and some bony corpuscles in the peripheral retina OU. Visual field analysis OU showed marked constriction in the peripheral visual fields (Figures 1 and 2). The findings were suggestive of RP.

The intervention adopted reflected the treatment for Timira and Kacha according to Vagbhata, viz., administrations of Snehana (therapeutic oleation), Asra-visravana (blood-letting), Reka (purgation), Nasya (medication through the nasal route), Anjana(collyrium), Murdha-basti (retention of oil over the head region), Basti Kriya (therapeutic enema), Tarpana (lubrication of the eye), Lepa (anointment), and Seka (ocular therapy by streaming). ${ }^{6}$

The patient's first round of treatment was from 25/09/2018 - 15/10/2018, and his second round of treatment was from 12/08/2019 - 22/08/2019. Oral medicines such as Kvatha (decoction), Ghrta (clarified butter), and tablets (Table 2); Panchakarma therapies such as Snehapana (therapeutic oleation), Svedana (sudation therapy), Virecana (therapeutic purgation), and Marsa Nasya (high dose medication through the nose) (Table 3); and external therapies for the eye (Netra Kriyakalpa) and head such as Netradhara (ocular therapy by streaming), Hasta Pada Abhyanga (therapeutic massage over the hands and feet), Pratimarsa Nasya (low-dose medi- cation through the nasal route), Anjana, Sirodhara (therapeutic streaming over the head), Ascyotana (eye drops), Siro-veshtanam (application of paste over the head on a Cora cloth), Bandhana (bandaging), Mukha Dhanya Pinda Sveda (facial sudation by applying poultice made from sour grains), Drishti Prasadana (massage over the eyelids using ghee), and Netra Tarpana (lubrication of the eye) (Table 4) were prescribed during the two courses of treatment.

During Snehapana, the patient was advised to observe strict rest and abstain from consuming oily and fried foods. A total of 5 Vegas (urges) were noted between 6:30am and 11:30am during Virecana, after which, Peya (thin gruel of rice) was administered as Samsarjana Krama (post-therapy dietetic regimen for revival).

All medicines, except Septillin tablet, were manufactured at Sreedhareeyam Farmherbs India, Pvt. Ltd., the hospital's GMP-certified drug manufacturing unit. Septillin Tablet was manufactured by The Himalaya Company, based in Bengaluru, Karnataka, India.

\section{RESULT}

DVA was LogMAR $0.477 \mathrm{OU}$, which was improvable to LogMAR 0.176 OU with cylindrical lenses of $-1.25 \mathrm{D}$ OD and $-0.5 \mathrm{D}$ OS after the first course of treatment on October 15th, 2018. NVA was maintained at N6 OU. The same visual acuity was maintained at admission to, and at discharge after, the second course of treatment. Refraction at discharge after the second course of treatment demonstrated LogMAR 0 OU with cylinder lenses of $-1.25 \mathrm{D}$ OD and $-0.5 \mathrm{D}$ OS. Fundus examination by ophthalmoscopy showed no further progression in the attenuated blood vessels and bony corpuscles. Visual field analysis showed markedly wider peripheral visual fields OU (Figures 3 and 4).

A timeline of events for this case is provided in Table 5.

\section{DISCUSSION}

Ayurveda explains that genetic diseases, which are a result of abnormalities in the Bija (sperm or ovum) brought about by improper activities of the parents and divine providence, increase all the Doshas and the resultant condition, as well as all hereditary conditions, is Asadhya (incurable) ${ }^{12}$ Hereditary defects in an organ happen when it is vitiated due to the part of the Bija responsible for the formation of that organ becoming vitiated itself. ${ }^{13}$ In this patient, a genetic defect resulting in retinitis pigmentosa occurred despite a normal pregnancy and delivery course.

Kapha Vidagdha Drishti occurs when the person perceives objects as white due to the Doshas lodging in the first and 
second Patalas (layers of the eyeball). When the Doshas advance to the $3^{\text {rd }}$ Patala, the person sees during the day and not at night because of Kapha Dosha. ${ }^{14}$

Snehapana was done as a Samana Cikitsa (pacifying treatment) for this patient, with $30 \mathrm{~mL}$ of ghee administered each day so as to not increase Kapha further. Avipattikara Yoga was selected for Virecana as it is apt for all Pitta (Dosha responsible for regulating body temperature and metabolic activities) conditions. The ingredients of Jivantyadi Taila pacified Vata and Pitta. Saptamrta Lauha is Tridosha Prasamana (pacifies the Tridosha), Rakta Prasadana (enhancing the quality of blood tissue), Rasayana (rejuvenative), and Cakshushya (Dravya or intervention good for eyesight). Asvagandha is Kapha-Vata Samana (pacifies Kapha and Vata), Balya (strength, stamina, and immunity promoter), Rakta Prasadana, and Rasayana. These medicines enhanced blood quality, relieved Tridosha, and prolonged the retinal dystrophy by revitalizing the tissue. Bharngyadi Kvatha is Vata-Kapha Samana, Dipana, and Srotosodhana (cleansing the structural or functional channels). Dasamula Katutraya Kvatha is Vata-Kapha Samana, Dipana, and Lekhana (therapeutic scraping). Sudarsanam Tablet, the tablet form of the original Curna, is Tridosa Prasamana, Amapacana (enhancing digestion). The combined effect of these three medicines helped to enhance digestion, reduce Doshas, and make available essential nutrients by clearing the channels. Local external treatments enabled efficient absorption and transport of the medicines to the target tissue, the retina, by obviating the blood-aqueous, blood-vitreous, and blood-retinal barriers.

Siroveshtanam is a variant of Sirolepa in which the paste is applied to the head in a Cora cloth and tied in the following manner: One end is placed over the right ear, the cloth is wrapped over the forehead and towards the left ear, taken over the back of the head toward the occiput, and brought over the head towards the right ear. Drishtiprasadanam is a procedure in which lukewarm Sneha is taken and massaged over the forehead and eyelids while applying pressure to the forehead, inner and outer canthus, and the supraorbital notch. Kasyapam Kvatha and Saptamrta Kvatha are indicated in all Netra Rogas (eye diseases). Timiranjana, Nakulanjana, and Nayanamrtam are Sita Virya (potency of coldness) and Ropana (healing) by nature. Sasanka Taila is Sita Virya by nature, and pacifies Pitta Dosha. Vinayakanjana is Ropana and is indicated in all Netra Roga. Jatavedha Ghrta and Ananta Ghrta are excellent for Netra Tarpana (lubrication of the eye).

\section{CONCLUSION}

The main challenge, in this case, was maintenance of vision and prolonging the dystrophy. However, positive results were obtained in both fields after two courses of Ayurvedic treatment. Repeated courses of treatment may aid to at least maintain vision and prolonging further progression of the disease. The results obtained in this case may be validated and analyzed by large-scale studies and trials.

\section{Abbreviations:}

RP: retinitis pigmentosa

DVA: distant visual acuity

NVA: near visual acuity

OD: oculus dexter

OS: oculus sinister

OU: oculus uterque

\section{ACKNOWLEDGMENT}

The authors thank Sreedhareeyam Ayurvedic Eye Hospital and Research Center, and Sreedhareeyam Farmherbs India Pvt. Ltd., for their help in preparing this case report. The authors acknowledge the immense help received from the scholars whose articles are cited and included in references of this manuscript. The authors are also grateful to the authors/editors/publishers of all those articles, journals, and books from where the literature for this article has been reviewed and discussed.

Conflicts of Interest: None declared

Sources of Funding: None declared

\section{REFERENCES}

1. Hamel C, Retinitis pigmentosa, Orphanet Journal of Rare Diseases, 2006, Vol. 40, pg. 2

2. Parmeggiani F, Clinics, Epidemiology, and Genetics of Retinitis Pigmentosa, Current Genomics, June 2011, Vol. 12, Issue 4, pgs. 236-237

3. Lim IJ, Akkara JD, Epley D, Shah VA, Carrera W, 2019, Retinitis Pigmentosa, Retrieved from https://eyewiki.aao.org/Retinitis_Pigmentosa

4. Gagnier J, Kienle G, Altman DG, Moher D, Sox H, Riley DS, CARE group, The CARE guidelines: Consensus-based clinical case-reporting guideline development, Global Advances in Health and Medicine, 2013, Vol. 2, Issue 5, pgs. 38-43

5. Byadgi PS, Ayurvediya Vikrti Vijnana and Roga Vijnana, Vol. 1, Chaukhambha Orientalia, Varanasi, 2004, pg. 300

6. Murthy KRS., Ashtangahrdaya of Vagbhata: Text, English Translation, Notes, Appendices, and Index, Vol. III, Uttara Sthana, Krishnadas Academy, Varanasi, Reprint 2000, pg. 121

7. Krishnan Vaidyan KV, Gopala Pillai S, Sahasrayogam: Sujanapriya Commentary, Vidyarambham Publishers, Alappuzha, 2006, pg. 34

8. Murthy PHC, Sarngadhara Samhita: Text with English Translation, Chaukhambha Orientalia, Varanasi, 2010, pg. 156

9. Murthy KRS., Ashtangahrdaya of Vagbhata: Text, English Translation, Notes, Appendices, and Index, Vol. II, Nidana, Cikitsa, and Kalpa-Siddhi Sthana, Krishnadas Academy, Varanasi, Reprint 2000, pg. 540 
10. Krishnan Vaidyan KV, Gopala Pillai S, Sahasrayogam: Sujanapriya Commentary, Vidyarambham Publishers, Alappuzha, 2006, pg. 286

11. Murthy KRS., Ashtangahrdaya of Vagbhata: Text, English Translation, Notes, Appendices, and Index, Vol. I, Sutra and Sarira Sthana, Krishnadas Academy, Varanasi, Reprint 2000, pg.

12. Murthy KRS., Ashtangahrdaya of Vagbhata: Text, English Translation, Notes, Appendices, and Index, Vol. II, Nidana, Cikitsa, and Kalpa-Siddhi Sthana, Krishnadas Academy, Varanasi, Reprint 2000, pg. 67
13. Sharma RK, Dash B, Caraka Samhita: Text with English Translation and Critical Exposition based on Cakrapani Datta's Ayurveda Dipika, Vol. II, Nidana, Vimana, Sarira, and Indriya Sthanas, Chaukhambha Krishnadas Academy, Varanasi, Reprint 2005, pg. 382

14. Sharma PV, Susruta Samhita: With English Translation of Text and Dalhana's Commentary alongwith Critical Notes Vol. III: Kalpasthana and Uttara Tantra, Chaukhambha Vishwabharati, Varanasi, Reprint 2010, pg. 145

Table 1: Dasavidha Pariksha

\begin{tabular}{ll} 
Parameter & Findings \\
Prakrti (somatic constitution) & Kapha-Vata \\
Vikrti (pathological factors) & Dosha (humor): Sannipata (three Doshas) \\
& Dushya: (tissues): Rasa (lymph) \\
Sara (essence of tissues) & Rakta (blood) \\
Samhanana (compactness) & Madhyama (medum) \\
Pramana (measurement) & Sama (equal) \\
Sattva (psyche) & Madhyama \\
Satmya (homologation) & Madhyama \\
Ahara Sakti (power of intake and digestion of food) & Pravara (optimum) \\
Vyayama Sakti (power of physical strength) & Madhyama \\
Vayah (age) & Madhyama \\
\hline
\end{tabular}

Table 2: Oral Medicines

\begin{tabular}{|c|c|c|c|c|c|}
\hline $\begin{array}{l}\text { Si. } \\
\text { No. }\end{array}$ & Medicine & Dosage & Anupana & Time & Duration \\
\hline 1 & Netraraksha Kvatha* & $60 \mathrm{~mL}$ & Warm water & $\begin{array}{l}\text { Twice a day before } \\
\text { food }\end{array}$ & $\begin{array}{c}25 / 09 / 2018-03 / 10 / 2018,05 / 10 / 2018- \\
15 / 10 / 2018\end{array}$ \\
\hline & & & & & $16 / 08 / 2019-26 / 08 / 2019$ \\
\hline 2 & Saptamrta Lauha7 & 1 tablet & $\begin{array}{l}\text { Netraraksha } \\
\text { Kvatha* }\end{array}$ & $\begin{array}{l}\text { Twice a day before } \\
\text { food }\end{array}$ & $\begin{array}{c}25 / 09 / 2018-03 / 10 / 2018,05 / 10 / 2018- \\
15 / 10 / 2018\end{array}$ \\
\hline 3 & Asvagandha Tablet & 1 tablet & Warm water & Twice a day after food & $\begin{array}{c}25 / 09 / 2018-03 / 10 / 2018 \\
05 / 10 / 2018-15 / 10 / 2018\end{array}$ \\
\hline 4 & Saptamrta Kvatha* & 6omL & Warm water & $\begin{array}{l}\text { Twice a day before } \\
\text { food }\end{array}$ & $06 / 10 / 2018-15 / 10 / 2018$ \\
\hline 5 & Bharngyadi Kvatha & 6omL & Warm water & $\begin{array}{l}\text { Twice a day before } \\
\text { food }\end{array}$ & $13 / 08 / 2019-15 / 08 / 2019$ \\
\hline 6 & $\begin{array}{l}\text { Dasamula Katutrayam } \\
\text { Kvatha }\end{array}$ & $6 o m L$ & Warm water & $\begin{array}{l}\text { Twice a day before } \\
\text { food }\end{array}$ & $13 / 08 / 2019-15 / 08 / 2019$ \\
\hline 7 & Sudarsanam Gutika ${ }^{8}$ & 2 tablets & Warm water & Twice a day after food & $13 / 08 / 2019-26 / 08 / 2019$ \\
\hline 8 & Septillin Tablet $^{\wedge}$ & 1 tablet & Warm water & Twice a day after food & $13 / 08 / 2019-26 / 08 / 2019$ \\
\hline
\end{tabular}


Table 3: Panchakarma Procedures

\begin{tabular}{|c|c|c|c|}
\hline Treatment & Medicine & Procedure & Duration \\
\hline Snehapana & Vainateya Ghrta* & $\begin{array}{l}30 \mathrm{~mL} \text { of ghee was administered at } 6 \mathrm{am} \text { in the morn- } \\
\text { ing on an empty stomach. }\end{array}$ & $27 / 09 / 2018-02 / 10 / 2018$ \\
\hline Svedana & Satapaka Taila* & $\begin{array}{l}\text { A full-body massage was done using the oil. The } \\
\text { patient was asked to take bath with hot water. }\end{array}$ & $03 / 10 / 2018$ \\
\hline Virecana & $\begin{array}{l}\text { Trvrt Lehya9 and } \\
\text { Triphala Kvatha }\end{array}$ & $\begin{array}{l}20 g \text { of Lehya and } 60 \mathrm{~mL} \text { of Kvatha were administered } \\
\text { in the morning. The urges were recorded }\end{array}$ & $04 / 10 / 2018$ \\
\hline Marsa Nasya & Jivantyadi Taila* & $\begin{array}{l}\text { Abhyanga was done with Kshirabala Taila. Then, } \\
8 \text { drops of Jivantyadi Taila were instilled into each } \\
\text { nostril. }\end{array}$ & $\begin{array}{c}05 / 10 / 2018-07 / 10 / 2018 \\
19 / 08 / 2019\end{array}$ \\
\hline
\end{tabular}

\section{Table 4: External Therapies}

\begin{tabular}{|c|c|c|c|c|}
\hline Therapy & Medicine & Procedure & Time & Duration \\
\hline Netra Dhara ${ }^{\circ}$ & Kasyapam Kvatha* & $\begin{array}{l}\text { 3omL of the decoction was poured } \\
\text { over the eyes with the patient being } \\
\text { asked to blink. }\end{array}$ & $\begin{array}{l}\text { Morning } \\
\text { and After- } \\
\text { noon }\end{array}$ & $\begin{array}{l}27 / 09 / 2018-03 / 10 / 2018 \\
05 / 10 / 2018-06 / 10 / 2018 \\
12 / 08 / 2019-18 / 08 / 2019\end{array}$ \\
\hline Anjana $^{\circ}$ & $\begin{array}{l}\text { Timiranjana* } \\
\text { Nakulanjana* }\end{array}$ & $\begin{array}{l}1 \text { drop of the medicine were instilled } \\
\text { into the eye at the inner canthus, and } \\
\text { the patient was asked to roll the eyes } \\
\text { around while closed. }\end{array}$ & $\begin{array}{l}\text { Morning } \\
\text { and After- } \\
\text { noon }\end{array}$ & $\begin{array}{l}25 / 09 / 2018-03 / 10 / 2018 \\
27 / 09 / 2018-06 / 10 / 2018 \\
12 / 08 / 2019-18 / 08 / 2019\end{array}$ \\
\hline & Nayanamrta* & & & $12 / 08 / 2019-18 / 08 / 2019$ \\
\hline Hasta Pada Abhyanga & $\begin{array}{l}\text { Dhanvantara Taila }{ }^{10} \\
\text { Kshirabala Taila }\end{array}$ & $\begin{array}{l}\text { 3omL of oil was taken and slightly } \\
\text { heated. This was then applied to the } \\
\text { hands and feet and massaged. }\end{array}$ & Morning & $\begin{array}{l}26 / 09 / 2018 \\
13 / 08 / 2019-16 / 08 / 2019\end{array}$ \\
\hline Sirodhara & $\begin{array}{l}\text { Kshirabala Taila } \\
\text { Sasanka Taila* }\end{array}$ & $\begin{array}{l}\text { A thin stream of oil was poured } \\
\text { through a coconut shell with a hole in } \\
\text { the center over the patient's head. }\end{array}$ & Morning & $\begin{array}{l}27 / 09 / 2018-02 / 10 / 2018 \\
17 / 08 / 2019-22 / 08 / 2019\end{array}$ \\
\hline Siroveshtanam $^{\circ}$ & $\begin{array}{l}\text { Bala, Vidari, Kacchuradi } \\
\text { Churna in Balasvagand- } \\
\text { hadi Taila }\end{array}$ & $\begin{array}{l}\text { A paste was prepared from the ingre- } \\
\text { dients and smeared over a Cora cloth. } \\
\text { This was applied over the right ear, } \\
\text { around the forehead, over the left ear, } \\
\text { and over the occiput. }\end{array}$ & Morning & $13 / 08 / 2019-15 / 08 / 2019$ \\
\hline $\begin{array}{l}\text { Mukha Dhanya Pinda } \\
\text { Sveda }\end{array}$ & & $\begin{array}{l}\text { Lukewarm grains were made into a } \\
\text { poultice and gently applied over the } \\
\text { face. }\end{array}$ & Morning & $20 / 08 / 2019-22 / 08 / 2019$ \\
\hline Pratimarsa Nasya & Anutaila $^{11}$ & $\begin{array}{l}3 \text { drops of lukewarm oil were instilled } \\
\text { into each nostril after massage over } \\
\text { the face. }\end{array}$ & Morning & $\begin{array}{l}27 / 09 / 2018-02 / 10 / 2018 \\
16 / 08 / 2019-18 / 08 / 2019\end{array}$ \\
\hline Drshtiprasadana $^{\circ}$ & $\begin{array}{l}\text { Kshirabala } 101 \text { Avartana } \\
\text { Taila }\end{array}$ & $\begin{array}{l}5 \text { drops of oil were taken and massage } \\
\text { was done over the forehead, upper } \\
\text { eyelid, and lower eyelid }\end{array}$ & Morning & $17 / 08 / 2019-19 / 08 / 2019$ \\
\hline Tarpana & $\begin{array}{l}\text { Ananta Ghrta* and Jata- } \\
\text { vedha Ghrta* }\end{array}$ & $\begin{array}{l}\text { A circular fence was constructed } \\
\text { around the orbits using Masha flour } \\
\text { and water. The medicine, made } \\
\text { lukewarm, was poured into the cavi- } \\
\text { ties. The patient was asked to blink } \\
\text { frequently. }\end{array}$ & Afternoon & $20 / 08 / 2019-26 / 08 / 2019$ \\
\hline $\begin{array}{l}\text { Ascyotana and Band- } \\
\text { hana }\end{array}$ & & $\begin{array}{l}\text { One drop of medicine was instilled } \\
\text { into the inner canthus. Afterward, } \\
\text { Malati Pushpa was applied to the eyes } \\
\text { and bandaging was done for one hour. }\end{array}$ & Morning & 20/08/2019 \\
\hline
\end{tabular}

*Patented medicines of Sreedhareeyam Ayurvedic Eye Hospital and Research Center

$\wedge$ Patented medicine of Himalaya Drug Company

${ }^{\circ}$ Treatment protocols of Sreedhareeyam Ayurvedic Eye Hospital and Research Center 
Table 5: Timeline of Events

\begin{tabular}{|c|c|}
\hline Date & Event \\
\hline 1983 & The patient gradually develops night blindness, for which he is prescribed vitamin A tablets \\
\hline 1990 & Develops difficulty in distant vision, is diagnosed with myopia, and is prescribed corrective glasses \\
\hline 2018 & Diagnosed with retinitis pigmentosa \\
\hline September $25^{\text {th }}, 2018$ & $\begin{array}{l}\text { First consultation with Sreedhareeyam; advised inpatient management. } \\
\text { Uncorrected DVA: LogMAR o.602 OU } \\
\text { Aided DVA: LogMAR 0.477 OD and LogMAR 0.301 OS } \\
\text { Refraction: LogMAR 0.301 OU with a -1D cylinder OD and -1.25D cylinder OS. } \\
\text { NVA: N6 OU } \\
\text { Visual Fields: Constricted peripheral fields OU } \\
\text { Oral medicines, viz., Netraraksha Kvatha*, Saptamrta Lauha, and Asvagandha Tablet are started. } \\
\text { Anjana^ with Timiranjana* is started. }\end{array}$ \\
\hline September $26^{\text {th }}, 2018$ & Hasta Pada Abhyanga with Dhanvantara Taila is done. \\
\hline September $27^{\text {th }}, 2018$ & 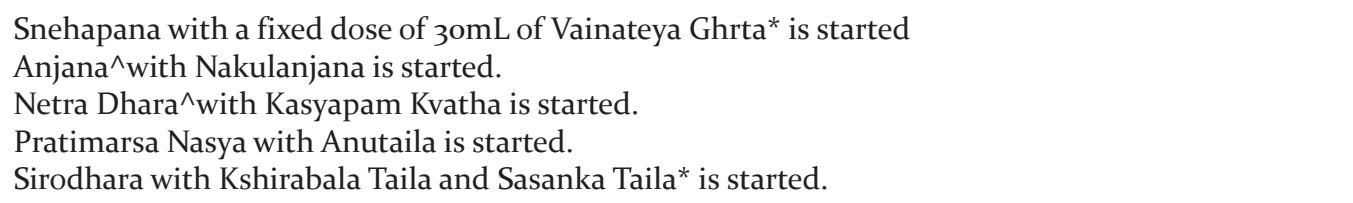 \\
\hline October $3^{\text {rd }}, 2018$ & $\begin{array}{l}\text { Svedana is done by Sarvanga Abhyanga (full-body massage) with Satapaka Taila and hot-water bath. } \\
\text { Anjana^ }{ }^{\wedge} \text { ith Timiranjana*and Netra Dhara^ are stopped. } \\
\text { Pratimarsa Nasya is stopped. } \\
\text { Sirodhara is stopped. } \\
\text { Oral medicines are stopped. }\end{array}$ \\
\hline October $4^{\text {th }}, 2018$ & Virecana is induced with Triphala Kvatha and Trvrt Lehya; a total of 5 urges are recorded \\
\hline October $5^{\text {th }}, 2018$ & $\begin{array}{l}\text { Oral medicines are restarted. } \\
\text { Netra Dhara^is restarted. } \\
\text { Saptamrta Kvatha* is started. }\end{array}$ \\
\hline October $6^{\text {th }}, 2018$ & $\begin{array}{l}\text { Netra Dhara is stopped. } \\
\text { Anjana with Nakulanjana* is stopped. }\end{array}$ \\
\hline October $7^{\text {th }}, 2018$ & Tarpana with Ananta Ghrta* and Jatavedha Ghrta* is started. \\
\hline October $15^{\text {th }}, 2018$ & $\begin{array}{l}\text { All treatments are stopped. } \\
\text { Patient is discharged with instructions for regular follow-up. } \\
\text { Unaided DVA: 6/18 Snellen (LogMAR o.477) OU } \\
\text { Aided DVA: 6/9 OU } \\
\text { Refraction: 6/6 OU with cylinder lenses of -1.25D OD and -0.5D OS. } \\
\text { NVA: N6 OU. }\end{array}$ \\
\hline August $13^{\text {th }}, 2019$ & $\begin{array}{l}\text { Patient reports for the second course of treatment. } \\
\text { Unaided DVA: LogMAR o.477 OU } \\
\text { Aided DVA: LogMAR o.176 OU } \\
\text { Refraction: LogMAR o OU with cylinder lenses of }-1.25 \text { D OD and -0.5D OS. } \\
\text { NVA: N6 OU } \\
\text { Oral medicines, viz., Bharngyadi Kvatha, Dasamula Katutrayam Kvatha, Sudarsanam Gutika, and } \\
\text { Septilin Tablet, are started. } \\
\text { Netra Dhara^ with Kasyapam Kvatha is started. } \\
\text { Anjana^with Nakulanjana* and Nayanamrtam*are started. } \\
\text { Hasta Pada Abhyanga with Kshirabala Taila is started. } \\
\text { Siroveshtana^ with Bala, Vidari, and Kaccuradi Churna in Balasvagandhadi Taila is started. }\end{array}$ \\
\hline August $15^{\text {th }}, 2019$ & $\begin{array}{l}\text { Bharngyadi Kvatha and Dasamula Katutrayam Kvatha are stopped. } \\
\text { Siroveshtana^is stopped. }\end{array}$ \\
\hline August $16^{\text {th }}, 2019$ & $\begin{array}{l}\text { Netraraksha Kvatha* is started. } \\
\text { Pratimarsa Nasya is started. } \\
\text { Hasta Pada Abhyanga is stopped. }\end{array}$ \\
\hline August $17^{\text {th }}, 2019$ & Drishti Prasadana^ with Kshirabala 101 Avartana Taila is started. \\
\hline August $18^{\text {th }}, 2019$ & Anjana^ and Pratimarsa Nasya are stopped. \\
\hline
\end{tabular}


Table 5: (Continued)

\begin{tabular}{ll} 
Date & Event \\
August $19^{\text {th }}, 2019$ & Drishti Prasadana is stopped. \\
August $20^{\text {th }}, 2019$ & Ascyotana with Ananta Ghrta* and Jatavedha Ghrta* is done, with Bandhana for 1 hour with jasmine \\
& flowers. \\
& Tarpana with Ananta Ghrta* and Jatavedha Ghrta* is started. \\
August $26^{\text {th }}, 2019$ & All treatments and oral medicines are stopped. \\
& Unaided DVA: 6/18 Snellen (LogMAR o.477) OU \\
& Aided DVA: LogMAR o.176 OU \\
& Refraction: LogMAR o OU with cylinder lenses of -1.25 D OD and -0.5D OS. \\
& NVA: N6 OU \\
& Visual Fields: Widened peripheral fields OU \\
\hline
\end{tabular}

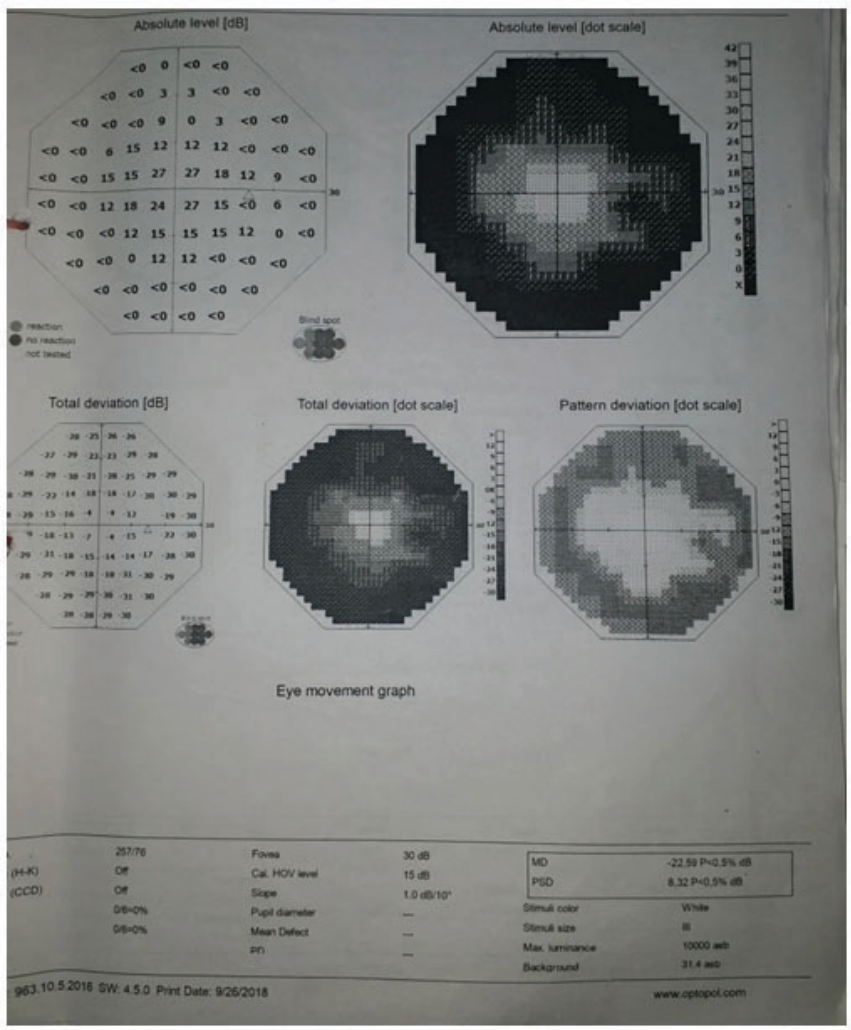

Figure 1: Visual field analysis OD at Admission before the First Course of Treatment.

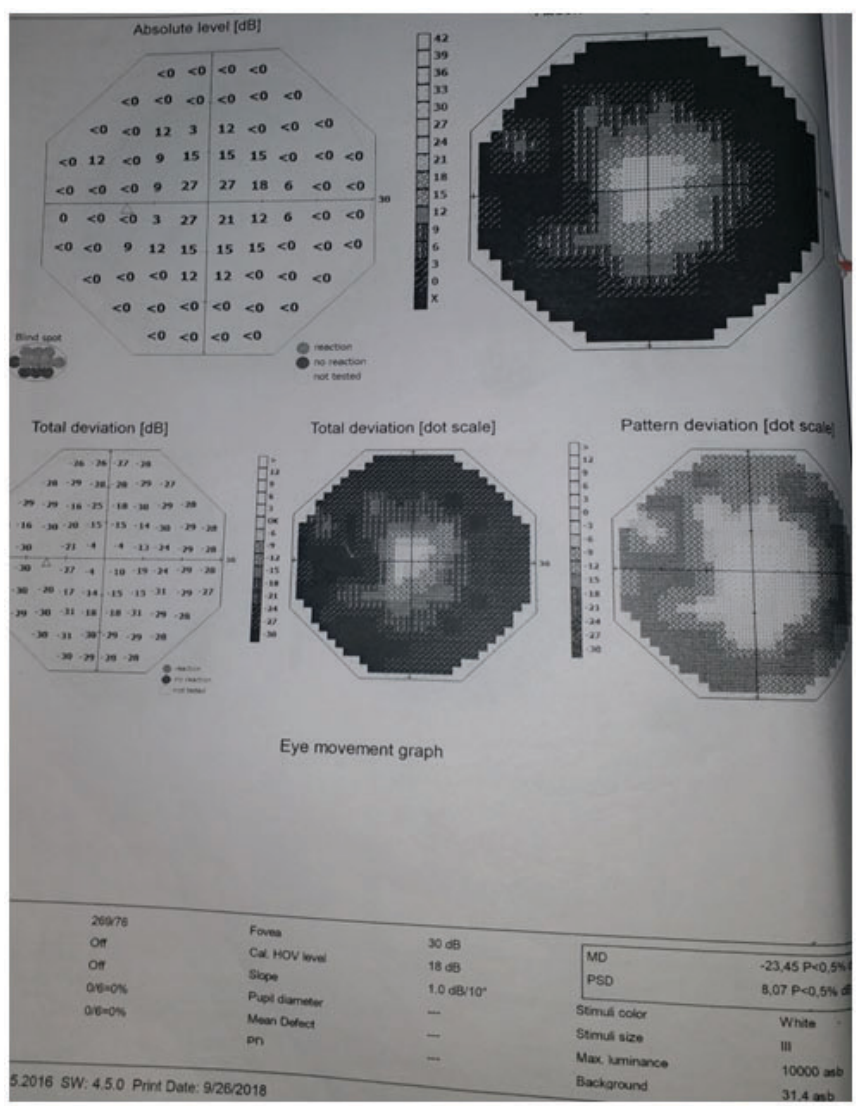

Figure 2: Visual field analysis OS at Admission before the First Course of Treatment. 


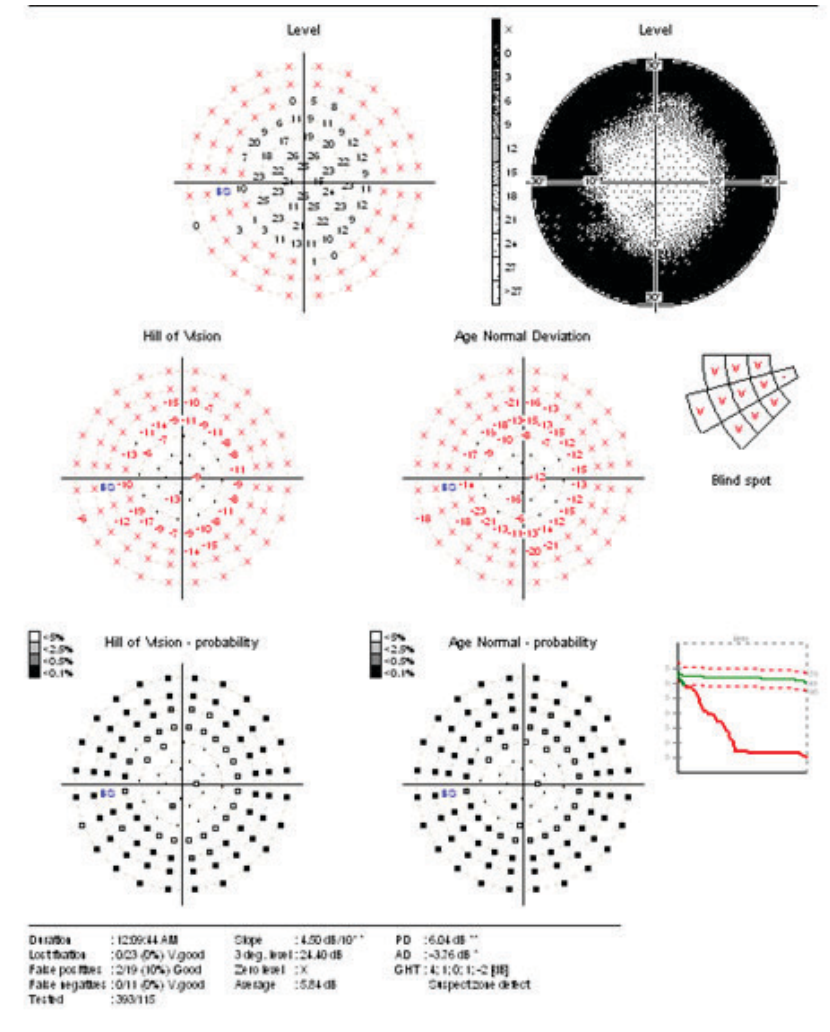

Figure 3: Visual field analysis OD at Dischargeafter the Second Course of Treatment.

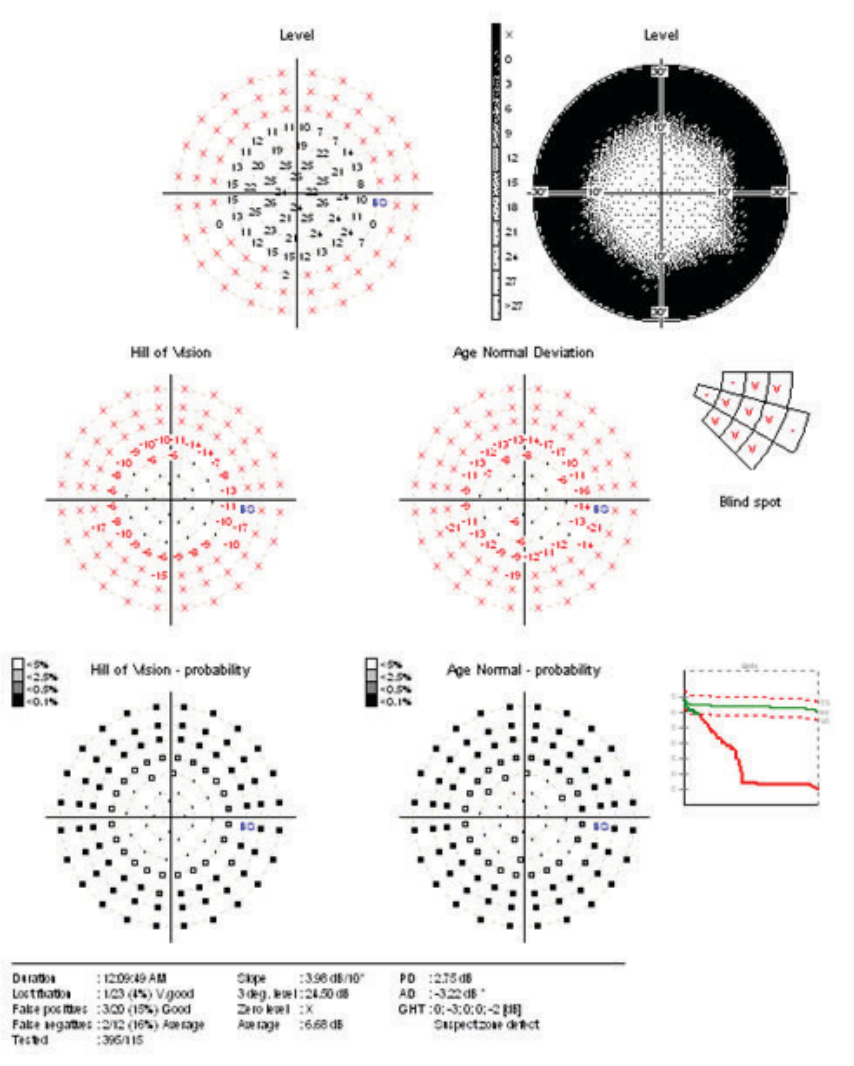

Figure 4: Visual field analysis OS at Discharge after the Second Course of Treatment. 